\title{
Factors Affecting Motivation and Job Satisfaction of Academic Staff of Universities in South-South Geopolitical Zone of Nigeria
}

\author{
Regina N. Osakwe ${ }^{1}$ \\ ${ }^{1}$ Department of Educational Administration and Policy Studies, Delta State University, Abraka, Nigeria \\ Correspondence: Regina N. Osakwe, Department of Educational Administration and Policy Studies, Delta State \\ University, Abraka, Nigeria. Tel: 803-501-0236. E-mail: nonyeosakwe@yahoo.co.uk
}

Received: February 10, 2014 Accepted: May 20, 2014 Online Published: June 19, 2014

doi:10.5539/ies.v7n $7 \mathrm{p} 43$

URL: http://dx.doi.org/10.5539/ies.v7n7p43

\begin{abstract}
This study determined the factors affecting motivation and job satisfaction of non-management academic staff of universities in South-South geopolitical zone of Nigeria. It employed an expost-facto research design. Three research questions and two hypotheses were raised for the study. A sample of four hundred and fifty non-management academic staff was administered the instrument for data collection. The instrument was vetted by three experts in the field of education, and face and content validity was established. The reliability coefficient of 0.82 was computed using Cronbach Alpha formula to measure the internal consistency of the questionnaire items. The three research questions were answered using mean and standard deviation, while the two hypotheses were tested using the z-test statistics at 0.05 level of significance. Results revealed that there is no significant difference between male and female non-management academic staff motivation and job satisfaction. It was also found that highly motivated non-management academic staffs perform their job better than poorly motivated staff. It was recommended that university authorities and the government should pay increasing attention to the motivation of non-management academic staff in order to boost their job performance and satisfaction thereby enhancing high productivity.
\end{abstract}

Keywords: academic staff, motivation, job satisfaction, factors, universities, Nigeria

\section{Introduction}

Education is essential to national growth and development. It helps individual to become self-reliant, skillful and good citizens. The future of any nation depends largely on the quality of its educational system. It further depends on the quality of its teachers. The maxim that no educational system can rise above the quality of its teaching staff implies the importance of teachers to national development. Teachers are instrumental to effective learning and quality education. They guide individual learners towards acquisition of knowledge, skills, abilities, information, ideas and competences needed for purposeful living. Imaobong (2000) sees a teacher as an individual who lays the moral foundation on which good citizenship is built. Thus a teacher's job goes beyond teaching. It stretches into moulding and guiding youths, monitoring students and promoting general character training. Teaching is a complex task and multi-dimensional in nature. Therefore, teachers need to be motivated for effective performance of, and dedication to their job. Ingwu and Ekefre (2006), Pilot (2007), Aldermon (2004) and Ngada (2003) observe that teacher motivation is a key to quality teaching and high standards of academic performance at all levels of education.

Universities are places where higher education in acquired. They are expected to discover and impart new knowledge, prepare people for leadership positions in all works of life and strive to promote equality and social justice. They are entrusted with the responsibility of providing semi-skilled and skilled workforce for the economy. The relevance of university and its conceived role as a major panacea for all societal problems has led to an unprecedented increase in social demand for education in Nigeria (Akpotu \& Nwadiani 2003; Chaugule, 2009). The number of federal and state universities has increased from 2 in 1960 to 117 in 2010/2011 academic year (NUC, 2010).

Academic staffs are essential to human capital development. Infact, many academic staff are specialists in their disciplines, have attained great academic heights and are hard to come by. Because their jobs have notional and global relevance, they tend to be very mobile (Akpotu \& Nwadiani, 2003). Academic staff job satisfaction is a predictor of their retention. It has an effect on school effectiveness, and influences job performance, motivation, 
morale and students performance. A positive and healthy university climate not only increase academic staff job satisfaction, but also improve learning and increases productivity.

Job satisfaction can simply be defined as the feelings people have about their jobs. It implies doing a job one enjoys well, and being suitably rewarded for one's efforts. It further implies enthusiasm and happiness with one's work. Armstrong (2006) defines job satisfaction as the attitudes and feelings people have about their work; positive and favourable attitudes indicate job satisfaction, while negative and unfavourable attitudes indicate job dissatisfaction. Okoth (2003) asserts that job satisfaction is a positive state, resulting from the appraisal of one's job experiences. It is the totality of positive feelings and beliefs that managers and workers have about their jobs. She further argues that managers whose job satisfaction is high generally like their job as they always feel that their jobs have desirable features such as interesting work, good pay and job security. According to Love and Edwards (2005), job satisfaction is a function of the match between the rewards offered by working conditions and the individual's preferences for those rewards. It is the extent to which employees favourably perceive their work (Gumato, 2003). Oshagbemi (2003) identifies job satisfaction as an important attribute which organizations expect their employees to possess. High job expectation indicates a strong correlation between an employee's expectation of the rewards accruing from a job and what the job actually provides. Workers who are satisfied with their job will be co-operative and well motivated while those who are dissatisfied will be inclined to produce low quality output, go on strike, be absent from work, invoke grievance procedures or, even leave the organization.

The level of job satisfaction is affected by intrinsic and extrinsic factors, the quality of supervision, social relationships with the work group and degree to which individuals succeed or fail in their work. Bavendum (2000) identifies six factors that promote job satisfaction, they are opportunity, good leadership, increase in relative strength, work standards, fair reward and adequate authority. Other factors are professional recognition, good salary, interpersonal relations, job security, professional advancement, favourable working conditions, supervision, achievement in work and promotion as and when due (Osakwe, 2003). Rhodes and Hammer (2000) note that the most important values or conditions conducive to job satisfaction are: mentally challenging work that the individual can cope with successfully, personal interest in the work itself, work which is not too physically tiring, rewards for performance, informative and in line with the individual's personal aspirations, working conditions which are compatible with the individual's physical needs and facilitate the accomplishment of his work goals, high self esteem on the part of the employee, agents in the workplace who help the employee to attain goals such as interesting work, pay and promotions whose basic values are similar to his own and which minimize role conflict and ambiguity. Job satisfaction points more at the extent to which employees have positive attitude towards their work. An attitude is an individual employee's feeling (satisfaction, indifference or dissatisfaction) towards a specific situation, object or person. Job satisfaction is the net result of the good attitude held by an individual employee at a given period of time. It is a result of employer's perception of how well their job provides those things which are viewed by them as important (Luthans, 2005).

The job expectations of university academic staff have diverged in recent years and seem to be growing exponentially, leading to a combination of increased job related stress and decreasing levels of morale and job satisfaction. Noordin (2009) and Muindi (2011) found that academic staff job satisfaction has significant relationship with their job performance and the academic performance of their students. Attitudes of academic staff are effected, in part, by workplace conditions such as a positive and safe environment, a supportive administration, career progression, commensurate salary, supportive work team, and the appeal of the job itself. It is also connected with their autonomy. Autonomy in the true sense, should be the privilege of the university system so as to enable it operate with full vigor for the fulfillment of goals and objectives. Academic autonomy, in relation to offering courses, evolving evaluation methods, teaching, research and extension activities is available. Financial autonomy is vital for continuation of universities as centers for excellence and the need, at present, is to initiate steps for fund generation and reduction of its dependence on the government to the extent possible, thus paving the way for self-reliance.

If academic staff are sidelined by stakeholders when matters affecting the work environment or revolving around university improvement are being discussed, the staff members may feel that, since they were not consulted, they are not stakeholders in the decision taken and so, would be unwilling to help make the decision a success. Also, when universities make decisions without seeking for or incorporating academic staff opinions, they would feel slighted and, hence, demoralized. This could lead to lack of motivation to support the decision reached (Briggs \& Richardson in Noordin \& Jusoff, 2009). This is a case of job dissatisfaction and may lead to negative consequences such as low productivity, intentional absenteeism, brain drain, tardiness, apathy, low job performance etc. The bottom line is that, it may lead to a situation that is detrimental to the health of the 
university.

Motivation is the inner force or urge that drives, directs, or influences an individual to attain organizational goals. It involves the biological, emotional, social and cognitive forces that translate wishes into action. Peretomode (2005) sees motivation as the process of influencing or stimulating a person to take action that will accomplish desired goals. He explained that teachers' motivation relates to a purposive and goal directed behaviour, performance and attitude towards work, stressing that such factors include physiological, psychological and environmental aspects of the individual employee's background. Academic staff motivation can arise from factors within the school system which, if favourable to them, could help improve their teaching effectiveness and thus improve on the quality output (students). Motivation is a key factor that determines the rate and success of the teaching-learning process. It also constitutes the main incentive that accelerates learning and the determination to preserve and sustain the long and often difficult teaching-learning process.

A motivated academic staff is one who not only feels satisfied with his or her job but is empowered to strive for excellence and growth in instructional practice. When academic staffs are motivated, they become satisfied and more committed to their teaching job. It eventually leads to or contributes positively to the attainment of educational goals and objectives. The more satisfied academic staff are with their job the more productive they will be, and the healthier they will be physically, emotionally, socially and academically. This is only possible if the necessary motivational factors that enhance job performance and satisfaction are in place. Motivational factors are those aspects of the job that make academic staff want to perform the duties. They help to propel, stimulate, channel, direct, energize, arouse, sustain and influence the teachers' behaviour towards striving for excellence. They also encourage academic staff and increase their persistence level in the teaching-learning process for the achievement of university educational goals and objectives. Researchers such as Rawsthorne and Elliot (1999), and Sansone and Harackiewiz (2000) are of the opinion that motivational factors (intrinsic motivation) make employees to persevere, work harder and produce result of higher quality. Other researchers such as Monahan (1996), Alderman (2004), Broussard and Garrison (2004), and Skinner (2006) argue that teachers who feel deprived of these factors are less motivated to do their best in the classroom. For academic staff to be committed to their job, university authorities, and the government should find ways to keep them in the profession by motivating them. Finally, we note that although a positive relationship exists between job satisfaction and job performance, it is moderated by the use of motivational factors and the nature of employees' attitude toward their job. This study therefore is poised to investigate the factors affecting job satisfaction and motivation of academic staff in South-South Geopolitical Zone of Nigeria.

\subsection{Statement of Problem}

One main problem facing the Nigerian non-management academic staff of public universities today seems to be lack of job satisfaction and motivation. It is widely believed that a worker who is well motivated and satisfied with his or her job is likely to perform his or her duties very efficiently. The duties of academic staff are quite enormous. Attitude of academic staff is affected by workforce conditions such as a positive and safe work environment, promotion, career progression, salary, team work, and the job itself. Also, when university authorities make decisions and behave as if academic staff opinions are not needed the academic staff would feel slighted and demoralized. This is an indication of the presence of job dissatisfaction. It may lead to negative consequences such as low productivity, intentional absenteeism, brain drain, apathy and low job performance. It is sad to note that because they lack job satisfaction, academic staffs leave the universities for the industrial and oil sectors of the economy. For these reasons, academic staff should be made to experience high levels of job satisfaction and motivation. Therefore, the problem of this study is: What are the factors affecting job satisfaction and motivation of non-management academic staff of state universities of South-South Geopolitical Zone of Nigeria.

\subsection{Research Questions}

The following research questions were asked to guide the study:

(1) What are the motivational factors that make non-management academic staff satisfied with their job?

(2) How can non-management academic staff be motivated by university authorities?

(3) Do male and female non-management academic staff differ in the motivational factors that affect motivation and their job satisfaction?

\subsubsection{Research Hypotheses}

The following null hypotheses were formulated and tested at 0.05 level of significance: 
There is no significant difference between male and female non-management academic staff in terms of motivation and job satisfaction.

There is no significant difference between the productivity of highly motivated non-management academic staff and that of poorly motivated non-management academic staff in terms of job satisfaction.

\subsubsection{Purpose of the Study}

The purpose of this study is to examine the factors affecting motivation and job satisfaction of non-management academic staff of universities in the South-South Geopolitical Zone of Nigeria. Specifically, the study will determine the following:

(1) The motivational factors that make non-management academic staff satisfied with their jobs and enhance productivity.

(2) How non-management academic staff can be motivated by university authorities.

(3) If there is any difference between male and female non-management academic staff in terms of motivation and job satisfaction.

(4) Whether there is a difference between the productivity (job performance) of highly motivated non-management academic staff and that of poorly motivated non-management academic staff.

\section{Method}

\subsection{Identify Subsections}

This section focuses on the procedures used in conducting this study. It describes the population (subjects) of the study, the sampling procedures and sample of the study, measures and covariates, design of the study and experimental manipulations that was used.

\subsection{Participant (Subject) Characteristics}

The population for the study comprised of all non-management members of academic staff in the six state universities in the South-South Geopolitical Zone of Nigeria. The South-South Geopolitical Zone comprises of six states (Delta, Edo, Cross Rivers, Bayelsa, Rivers, Akwa Ibom).

\subsection{Sampling Procedures}

For the purpose of sampling, the multistage and stratified sampling techniques were used. The sample selected was based on the characteristics of sex, qualification and experience. Out of the population of 4,500 staff, a sample of 450 academic staff was drawn representing $10 \%$ of the target population.

\subsubsection{Sample Size}

The sample size of this study was 450 non-management academic staff representing $10 \%$ of the population.

\subsubsection{Measures and Covariates}

A modified instrument tagged Motivational Factors and Academic Staff Job Satisfaction Questionnaire (MFASJSQ) was used for collecting data for the study. The instrument was structured using the 4 point likert type scale of measurement ranging from Strongly Agree (4) to Strongly Disagree (1). The face and content validity was established after subjecting the instrument to vetting by three experts in the field of education. The reliability of the instrument was ascertained using 30 academic staff who were not part of the study sample used. The reliability coefficient of the instrument of 0.82 was computed using Cronbach Alpha formula to measure the internal consistency of the questionnaire items. The questionnaires were administered to the respondents by the researcher with the aid of research assistants, and all the 450 copies administered were retrieved and used for data analysis showing $100 \%$ return rate.

\subsubsection{Research Design}

This study used an ex-post facto design in the sense that the researcher does not have control over independent variables due to the fact that they were not manipulated.

\subsubsection{Experimental Manipulations}

The data collected were analyzed using mean and standard deviation for research questions, and the decision rule of acceptance level is anything from 3.00 and above, while the rejection level is anything below 3.00. The hypotheses were analyzed using the z-test statistics which was tested at alpha level of significance of 0.05 . 


$$
\begin{aligned}
\bar{X} & =\frac{\epsilon x}{N} \\
S D & =\sqrt{\frac{\epsilon x-\epsilon x}{N(N-1)}} \\
Z & =\frac{X-\bar{X}}{S}
\end{aligned}
$$

\section{Results}

Research Question 1: What are the motivational factors that make non-management academic staff satisfied with their job?

Table 1. Mean and standard deviation of motivational factors and job satisfaction

\begin{tabular}{llllll}
\hline S/N & Motivational Factors and Job Satisfaction & \multicolumn{4}{l}{ Academic Staff Responses } \\
\hline & & $\mathrm{N}$ & $\bar{X}$ & $\mathrm{SD}$ & Decision \\
\hline 1. & Good salary and conditions of service. & 450 & 4.98 & 1.73 & Agreed \\
2. & Prompt and regular promotion. & 450 & 4.69 & 1.84 & Agreed \\
3. & Recognition and feedback. & 450 & 3.84 & 1.64 & Agreed \\
4. & Increased job security/enrichment. & 450 & 3.48 & 1.59 & Agreed \\
5. & Professional development (in service training and retraining). & 450 & 4.48 & 1.76 & Agreed \\
6. & Empowerment and authority. & 450 & 4.10 & 1.10 & Agreed \\
7. & Good working environment. & 450 & 3.86 & 1.89 & Agreed \\
8. & Work itself-challenging and varied work. & 450 & 3.22 & 0.73 & Agreed \\
9. & Participation in decision making. & 450 & 3.49 & 0.80 & Agreed \\
10. & Giving research grants. & 450 & 3.05 & 0.95 & Agreed \\
\hline & Cumulative Average & & 3.92 & & \\
\hline
\end{tabular}

Table 1 shows that all the sampled academic staff agreed that the items listed are motivational factors that make them to be satisfied with their jobs, since the mean values obtained were above 3.00 which is the acceptance level. This table also shows that the cumulative average mean of academic staff responses is 3.92.

Research Question 2: How can non-management academic staff be motivated by university authorities? 
Table 2. Mean and standard deviation of academic staff motivation by university authorities

\begin{tabular}{llllll}
\hline $\mathrm{S} / \mathrm{N}$ & Ways of Motivating Academic Staff & \multicolumn{3}{c}{ Academic Staff Responses } \\
\hline & & $\mathrm{N}$ & $\bar{X}$ & $\mathrm{SD}$ & Decision \\
\hline 1. & Creation of a pleasant work environment. & 450 & 4.60 & 2.64 & Agreed \\
2. & $\begin{array}{l}\text { Developing a school climate that encourages job security and enrichment. } \\
\text { 3. }\end{array}$ & 450 & 4.42 & 2.06 & Agreed \\
& $\begin{array}{l}\text { Providing professional development activities (seminars, workshops, } \\
\text { conference). }\end{array}$ & 450 & 3.25 & 2.12 & Agreed \\
4. & $\begin{array}{l}\text { Developing a school climate that gives academic staff the sense of } \\
\text { autonomy. }\end{array}$ & 450 & 3.60 & 1.29 & Agreed \\
5. & $\begin{array}{l}\text { Recognize individuals personal aspiration, needs and supportive of their } \\
\text { involvement in research. }\end{array}$ & 450 & 3.35 & 1.80 & Agreed \\
6. & $\begin{array}{l}\text { Involving staff in decision making. } \\
\text { 7. }\end{array} \quad$ Promoting staff as at when due. & 450 & 3.00 & 1.17 & Agreed \\
& Cumulative Average & 450 & 3.70 & 1.18 & Agreed \\
\hline
\end{tabular}

Table 2 indicates that academic staff agreed that they can be motivated by university authorities through the strategies mentioned above, hence they will be satisfied with their jobs. This table also indicated that the cumulative total mean average of academic staff motivation is 3.70 .

Research Question 3: Do male and female non-management academic staff differ in the motivational factors affecting motivation and their job satisfaction?

Table 3. Mean and standard deviation of male and female non-management academic staff motivational factors affecting motivation and job satisfaction

\begin{tabular}{|c|c|c|c|c|c|c|c|c|c|}
\hline \multirow[t]{2}{*}{$\mathrm{S} / \mathrm{N}$} & \multirow[t]{2}{*}{ Motivational Factors } & \multicolumn{2}{|c|}{$\begin{array}{l}\text { Male } \quad A \\
\text { Responses }\end{array}$} & \multicolumn{2}{|c|}{ cademic } & \multicolumn{2}{|c|}{$\begin{array}{l}\text { Female } \\
\text { Responses }\end{array}$} & Academic & Staff \\
\hline & & $\mathrm{N}$ & $\bar{X}$ & SD & Decision & $\mathrm{N}$ & $\bar{X}$ & SD & Decision \\
\hline 1. & Prompt promotion. & 190 & 3.96 & 1.78 & Agreed & 260 & 4.22 & 1.73 & Agreed \\
\hline 2. & $\begin{array}{l}\text { Good salaries and condition of } \\
\text { service. }\end{array}$ & 190 & 3.88 & 1.86 & Agreed & 260 & 4.06 & 1.84 & Agreed \\
\hline 3. & Recognition and feedback. & 190 & 3.85 & 1.84 & Agreed & 260 & 4.10 & 1.81 & Agreed \\
\hline 4. & Increased responsibility. & 190 & 3.49 & 1.60 & Agreed & 260 & 3.26 & 1.73 & Agreed \\
\hline 5. & $\begin{array}{l}\text { Professional development (in-service } \\
\text { training and retraining). }\end{array}$ & 190 & 3.71 & 1.90 & Agreed & 260 & 4.05 & 1.75 & Agreed \\
\hline 6. & Empowerment and authority. & 190 & 3.37 & 1.95 & Agreed & 260 & 3.80 & 1.81 & Agreed \\
\hline 7. & Positive school climate. & 190 & 3.88 & 1.86 & Agreed & 260 & 4.41 & 1.64 & Agreed \\
\hline 8. & $\begin{array}{l}\text { Work itself, that is challenging and } \\
\text { varied work. }\end{array}$ & 190 & 3.46 & 1.92 & Agreed & 260 & 3.38 & 1.89 & Agreed \\
\hline 9. & $\begin{array}{l}\text { Participation in decision-making } \\
\text { process of the university. }\end{array}$ & 190 & 3.35 & 1.64 & Agreed & 260 & 3.68 & 1.89 & Agreed \\
\hline 10. & $\begin{array}{l}\text { Supervisory practices of university } \\
\text { authority. }\end{array}$ & 190 & 3.05 & 1.75 & Agreed & 260 & 3.10 & 1.76 & Agreed \\
\hline & Cumulative Average & & 3.60 & & & & 3.84 & & \\
\hline
\end{tabular}

Table 3 reveals that both male and female academic staff agreed that the listed items are motivational factors affecting motivation and job satisfaction, thus enhancing their productivity. This is because the mean values of 
the motivational items exceeded the decision level of 3.00 which is the acceptance level. The table also reveals that the cumulative average means of male and female academic staff are 3.60 and 3.84 respectively. This means that factors that affect motivation and job satisfaction do not differ.

\section{Presentation of Hypotheses}

Hypothesis One: There is no significant difference between male and female non-management academic staff with regards to motivation and job satisfaction.

Table 4. Z-test analysis of male and female non-management academic staff motivation and job satisfaction

\begin{tabular}{ccccccccc}
\hline Variables & $\mathrm{N}$ & Mean & $\mathrm{SD}$ & $\mathrm{DF}$ & Z-cal. & Z-crit. & Level of Sign. & Decision \\
\hline Male & 190 & 10.36 & 4.28 & \multirow{4}{*}{1.59} & 1.96 & 0.05 & Retained \\
Female & 260 & 11.32 & 3.12 & & & & & \\
\hline
\end{tabular}

In table 4 , the z-calculated value of 1.59 is less than the z-critical value of 1.96 , hence the null hypothesis is retained. This shows a non-significant difference between male and female non-management academic staff with regards to motivation and job satisfaction. This implies that non-management academic staff are satisfied with their job when motivated thus enhancing their performance regardless of gender issues.

Hypothesis Two: There is no significant difference between the productivity of highly motivated non-management academic staff and that of poorly motivated non-management academic staff with regards to job satisfaction.

Table 5. Z-test analysis of the productivity of highly motivated and poorly motivated non-management academic staff

\begin{tabular}{ccccccccc}
\hline Variables & $\mathrm{N}$ & Mean & SD & DF & Z-cal. & Z-crit. & Level of Sign & Decision \\
\hline Highly motivated academic staff. & 150 & 38.28 & 23.82 & \multirow{2}{*}{448} & 6.85 & 1.96 & 0.05 & Rejected \\
Poorly motivated academic staff. & 300 & 11.32 & 9.82 & & & & & \\
\hline
\end{tabular}

Table 5 shows that the z-calculated value of 6.85 is greater than the z-critical value of 1.96 , hence the null hypothesis is rejected. This indicates that there is a significant difference between the productivity of highly motivated non-management academic staff and that of poorly motivated non-management academic staff in terms of job satisfaction.

\section{Discussion}

The study answered three questions and tested three hypotheses on factors affecting motivation and job satisfaction of non-management academic staff in the six state universities of South-South Geopolitical Zone of Nigeria. Results on research question 1 revealed that non-management academic staff agreed that the 10 items they responded to are motivational factors that give them job satisfaction. The factors are good salary and conditions of service, prompt and regular promotion, recognition and feedback, increased job security/enrichment, professional development programmes, empowerment and authority, good working environment, challenging and varied work, participation in decision making, and research grants.

University teachers also said they could be motivated by university authority if the latter can introduce and apply strategies that have positive impact on them (university teachers). This is the implication of table two's results on research question 2. Table three's result reveals that male and female non-management academic staff are more satisfied with their job when they are motivated and hence enrich performance.

Results on hypothesis one show that motivational factors promote job satisfaction among academic staff gender difference notwithstanding. Male and female academic staff work harder and are more dedicated to their job when motivated to do so. This finding lend credence to the findings of Osakwe (2003), Alderman (2004), and Aguba (2009) which say that, irrespective of gender, teachers (academic staff) are more productive, satisfied with their job and healthier physically, emotionally, socially, and academically when motivated. They noted that 
a conducive school climate and job security influence teachers (academic staff) dedication to their job.

On hypothesis two, results show that highly motivated academic staffs are more satisfied and productive in their job than are poorly motivated ones. This finding is in line with Broussard \& Garrison (2004) and Skinner (2006) who argued that teachers (academic staff) who do not feel supported with these factors are less motivated to do their best in the classroom.

\section{Conclusion}

Motivational factors and academic staff job satisfaction happen to be the most note worthy subject in any university system. Motivation plays a vital role in the job satisfaction of academic staff. It enhances their productivity and is essential to a healthy and prosperous teaching-learning environment. The results of this study confirmed that there is no significant difference between male and female academic staff with regards to motivation and job satisfaction.

It was also found that, a significant difference exists between the productivity of highly motivated and poorly motivated non-management academic staff with regards to motivation and job satisfaction. This shows that highly motivated academic staffs perform better in the workplace.

The findings of this study justify the importance of motivational factors to the job satisfaction of academic staff. Thus, it can be said that the adequate productivity and performance in the teaching-learning process depends so much on the motivation of academic staff. In other words, the efficiency of academic staff depends, to a large extent, on motivational factors (work environment, promotion opportunities, autonomy, professional development, safety and security, empowerment and authority etc). The dispositions, attitudes, feelings and emotions of academic staff towards their job play a vital role in determining their performance, productivity and behaviour. These, in turn, determine the success and academic achievement of the students.

It is for this reason that university management, and the government should pay increasing attention to the motivation of university academic staff in order to boost their satisfaction with the job of teaching, research, assigned responsibilities and other extra-curricular activities.

\section{Recommendations}

Based on the findings of the study the following recommendations were made:

(1) University authorities and academic staff should work together in order to pave way for an atmosphere that is conducive to the education process.

(2) The government and university authorities should create a pleasant and supportive work environment that emphasizes the importance of academic achievement.

(3) Universities should develop a school climate that recognizes individual differences encourage creativity, and gives academic staff a sense of autonomy.

(4) They should recognize academic staff's individual learning/training needs and be supportive of their continuing education and involvement in research.

(5) University authorities should provide professional development forums (seminars, workshops, conferences, etc) and encourage academic staff to participate.

Academic staff should be involved in decision-making process.

\section{References}

Aguba, C. R. (2009). Educational administration and management: Issues and perspective. Enugu: Tons and Tons PDS.

Akpotu, N. E., \& Nwadiani, M. (2003). Factors influencing academic staff turnover in Nigerian universities. Higher Education Review, 36(1), 45-56.

Alderman, K. M. (2004). Motivation for achievement: Possibilities for teaching and learning. New Jersey: Lawrence Erlbaum Associates, Inc. Publishers.

Armstrong, M. (2006). A handbook of human resource management practice (10th ed.). London: Kogan Page.

Armstrong, M. (2009). Armstrong's handbook of human resource management practice (11th ed.). London: Kogan Page.

Bavendum, J. (2000). Managing job satisfaction. New York: New York Research Inc.

Broussard, S. H., \& Garrison, B. M. E. (2004). The relationship between classroom motivation and academic 
achievement in elementary school aged children. Family and Consumer Sciences Research Journal, 33(2), 106-120. http://dx.doi.org/10.1177/1077727X04269573

Chaugule, S. S. (2009). Job satisfaction of university employees. Free Articles by Articles Base.com. Posted: Sept 18, 2009/Comments/views:2,829/f(like).

Gumato, U. (2003). Survey of the relationship between the perceived empowerment and job satisfaction of employees in commercial banks in Nairobi (Unpublished MBA Research Project, University of Nairobi).

Imaobong, U. N. (2004). Teacher preparation for Nigerian basic education. Journal of Research in Education $1(1), 1-6$.

Ingwu, E. U., \& Ekefre, E. N. (2006). A framework for measurement of teacher productivity in Nigeria. Nigeria Journal of Education Philosophy, 2(2), 1-10.

Love, P. E. D., \& Edwards, D. J. (2005). Taking the pulse of UK construction project managers' health influence of job demands, job control and social support on Psychological wellbeing. Engineering, Construction and Architectural Management, 12(1), 88-101. http://dx.doi.org/10.1108/09699980510576916

Luthans, F. (2005). Organizational behaviour (10th ed.). New York: McGraw-Hill Irwin.

Muindi, F. K. (2011). The relationship between participation in decision making and job satisfaction among academic staff in the school of business, university of Nairobi. Journal of Human Resource Management Research. http://dx.doi.org/10.5171/2011.246460

Ngada, J. A. (2003). Challenges and future of teacher education in Nigeria. Multidisciplinary Journal of Research Development. National Universities Commission: VIHEP Information Booklet (2003-2004).

Noordin, F., \& Jusoff, K. (2009). Levels of job satisfaction amongst Malaysian academic staff. Asian Social Science, 5(5), 122-128.

Okoth, L. A. (2003). A survey of the factors that determine the level of job satisfaction among teachers in top ranking private schools in Nairobi (Unpublished MBA Project, University of Nairobi).

Osakwe, R. N. (2003). A comparative study of job satisfaction between public and private secondary school in Delta State (Unpublished Ph.D. thesis of the Faculty of Education, Delta State University, Abraka).

Oshagbemi, T. (2003). Personal correlates of job satisfaction: Empirical evidence from UK Universities. International Journal of Social $\quad$ Economics, $\quad 30(12), \quad$ 1210-1232. http://dx.doi.org/10.1108/03068290310500634

Peretomode, V. F. (2005). Educational administration, applied concepts and theoretical perspectives for students and practitioners. Lagos: Joja Publishers.

Rawsthorne, L. J., \& Elliot, A. J. (1999). Achievement goals and intrinsic motivation: A meta-analytic review. Personality and Social Psychology Review, 3, 326-344. http://dx.doi.org/10.1207/s15327957pspr0304_3

Rhodes, L. D., \& Hammer, E. Y. (2000). The relation between job satisfaction and personality similarity in supervisors and subordinates. Psi Chi Journal of Undergraduate Research, 1, 46-262.

Robert, S. F. (2002). Understanding Psychology (6th ed.). New York: McGraw Hill Companies, Inc.

Sansone, C. R., \& Harackiewicz, J. M. (Eds.). (2000). Intrinsic and extrinsic motivation. Orlando, FL: Academic Press.

Skinner, B. F. (2006). Wikipedia: The free encyclopedia (Electronic version). Retrieved from http://en/wikpedia.org/wiki/B.F.skinner

\section{Copyrights}

Copyright for this article is retained by the author(s), with first publication rights granted to the journal.

This is an open-access article distributed under the terms and conditions of the Creative Commons Attribution license (http://creativecommons.org/licenses/by/3.0/). 